MIKKEL BOLT

Lektor ved Institut for Kunst-og Kulturvidenskab, Københavns Universitet

\title{
'SLAPHEDENS' EPOKE' \\ ET BIDRAG TIL DEN RETROSPEKTIVE (POST-(?)/NEO-(?))MARXISTISKE KRITIK AF IDÉEN OM DET POSTMODERNE BRUD, ELLER: ALT VAR IKKE SPROGSPIL, OG HVOR VAR KAPITALEN, LYOTARD?
}

THE ERA OF RELAXATION. A CONTRIBUTION TO THE RETROSPECTIVE (POST(?)/NEO-(?)MARXIST CRITIQUE OF THE IDEA OF A POSTMODERN BREAK, OR; EVERYTHING WAS NOTJUST LANGUAGE GAMES, AND WHERE WAS CAPI-

TAL, LYOTARD? I Through a reading of the development of the philosophy of Jean-François Lyotard the article looks back at the critical revision of Marxism by a generation of French philosophers who were originally affiliated with Marxism themselves but ended up abandoning the Marxist analysis of the capitalist mode of production in favour of a position less critical towards capital.

KEYWORDS I postmodernism; marxism; Lyotard, Jean-François

Jeg lægger ud med et citat af Lyotard. Det er fra hans rapport om "videnstilstanden i de højtudviklede samfund" fra 1979, der er gået over i historien som et af de vigtigste skrifter i det postmoderne opbrud. Lyotard skriver: "Det økonomiske 'genopsving' i kapitalismens aktuelle fase, hjulpet frem af forandringerne inden for teknikken og teknologierne, sker samtidig [...] med en ændring af staternes funktion: ud fra dette syndrom danner der sig et billede af samfundet, som tvinger os til alvorligt at revidere de indfaldsvinkler, der her er blevet præsenteret som alternativer.” (33) De indfaldsvinkler, Lyotard henviser til, er systemteorien i alle dens former, der tænker samfundet som en sammenhængende størrelse, en funktionel helhed, fra funktionalistisk sociologi til kybernetik, men først og fremmest er det marxismen. Den funktionalistiske sociologi og marxismen har ifølge Lyotard fungeret som

I Lyotard skriver i teksten “Svar på spørgsmålet: Hvad er det postmoderne?” fra 1982, at tiden er kendetegnet ved "slap tænkning”. Han eksemplificerer med Jürgen Habermas, Germano Celant og en række kunstkritikere og arkitekter, der ifølge Lyotard alle forholder sig afvisende over for avantgardens eksperimenter og den kunstneriske søgen. 
de to vigtigste, konkurrerende samfundsmodeller i det I9. og det 20. århundrede. Men nu er de begge forældede, overhalet af en ny samfundsform, hvad Lyotard i bogen i forlængelse af den franske sociolog Alain Touraine og den konservative amerikanske kulturkritiker Daniel Bell benævner det postindustrielle eller det postmoderne samfund. Hvor den funktionalistiske sociologi betragter samfundet som en sammenhængende helhed, som en art selvregulerende system, der anskuer marxismen selvfølgeligt samfundet som karakteriseret af en grundlæggende modsætning mellem kapital og arbejde. Det moderne samfund er et kapitalistisk klassesamfund, og der er en uforenelig modsætning mellem kapitalen og proletariatet. Kapitalen tilegner sig herredømmet over arbejderklassens arbejdskraft med henblik på skabelsen af merværdi, der fremtræder i profitform som penge. Marxismen er den kritiske kortlægning af denne historiske uret, udvindingen af merværdi og udbytningen, en kortlægning med henblik på praksis, altså ophævelsen af kapitalismen og produktets vareform.

Den modsætning, som marxismen analytisk forsøger at eksponere (og politisk overvinde gennem klassekampen og ophævelsen af kapitalismen), er ifølge Lyotard imidlertid ved at forsvinde, hvorfor marxismen fremstår dateret, for ikke at sige egentlig forældet. Som Lyotard formulerer det i bogen: "Man kan ikke skjule, at den [marxismen] langt om længe, idet det sociale grundlag for opdelingsprincippet, klassekampen, er ved at forsvinde i et sådant omfang, at det mister enhver radikalitet, er blevet udsat for faren for at miste sit teoretiske fodfæste og blive reduceret til en 'utopi', et 'håb', en protest i menneskets eller i fornuftens eller i kreativitetens eller endnu mere i den og den sociale kategoris navn, som f.eks. den tredje verden eller studenterungdommen, der tillægges den fra nu af usandsynlige funktion som kritisk subjekt." (3I-32)

Den grundlæggende modsætning, som marxismen identificerer i kapitalismen og den kapitalistiske produktionsmåde, er simpelthen ved at forsvinde, skriver Lyotard. Marxismen forsøger ganske vist at finde en erstatning for proletariatet som historiens subjekt i eksempelvis de studerende, men løbet er kørt, konkluderer Lyotard. Marxismen er "en tænkning i modsætninger, der ikke svarer til den postmoderne videns mest levende former". (33) Det teoretiske fodfæste er smuldret under fødderne på marxismen, der er endt med ikke at være andet end et håb. Klassekampen er bare forbi. End of story. Den store fortælling om proletariatets fremtidige frigørelse fra fattigdom hænger ikke længere sammen og er uden basis i virkeligheden.

\section{Ud af historien}

Umiddelbart må man sige, at Lyotard på forfærdelig mange måder havde ret i sin påstand. Han havde ret i den forstand, at hans tese blev dagsordensættende, og at marxismen i løbet af få årtier mistede enhver legitimitet i den vestlige verden. Og forestillingen om klassekampen forsvandt næsten fuldstændig som en kritisk beskrivelse af samfundet. Fra i I950'erne at have været "den uoverskridelige ho- 
risont”, som Sartre formulerede det, blev marxismen en forældet analysemåde, der fortegnede konflikterne i de moderne samfund. Der var ikke længere tale om en tragisk historie om to sammenkædede, men uforenelige subjekter, kapital og arbejde, viet til klassekamp, "til en revolutionær omformning af hele samfundet eller de kæmpende klassers fælles undergang”, som Marx og Engels truende og apokalyptisk skrev det i Det kommunistiske partis manifest (I4). Denne store kritiske fortælling forsvandt.

Marxismens fokus på klasser og kapitalens dominans blev i perioden fra midten af I970'erne og frem tilsyneladende mindre og mindre aktuel. Marxismen gik fra at være et kritisk og revolutionært foretagende til at blive en historisk substitutreligion, som for en periode havde kunnet mobilisere store menneskemasser, men som nu var blevet gjort overflødig takket være den teknologiske udvikling. Lagt på plads i historien som endnu en ideologisk fantasi, som havde mistet sin betydning. Fra at have været dagsordensættende intellektuelt efter Anden Verdenskrig fra I940'ernes eksistentialisme frem til den strukturelle marxisme sidst i I96o'erne og kapitallogikken i I970'ernes begyndelse svandt marxismens indflydelse ind, og i løbet af I980'erne forsvandt marxismens mange forskellige retninger næsten helt. Efter Murens fald overlevede marxismen kun helt ude i marginen som forskellige residuale positioner, der på ingen måde havde nogen større breddevirkning.

Forestillingen om klassekamp fremstod mere og mere historisk, den dominerende fortælling om den vestlige verdens informationssamfund fokuserede i stedet på systemets evne til at korrigere eventuelle udsving. Klassekampen forsvandt, og idéen om revolution og kritik levede videre som fordringer til den enkelte om at være omstillingsparat og disponibel for markedets konstant skiftende krav. Som den engelske historiker Perry Anderson med resignation skrev i år 200o, var neoliberalismen den mest succesrige ideologi i verdenshistorien. "For første gang siden reformationen findes der ikke nogen reel opposition - dvs. sammenhængende konkurrerende forestillinger - inden for vestens tankeverden, og vel heller ikke på verdensplan. [...] Som princip regerer neoliberalismen uindskrænket i hele verden.” (I3) Thatchers såkaldte TINA-doktrin (There is no alternative) var blevet realiseret, der var ikke noget alternativ. Den neoliberale antimarxisme havde vind i sejlene. Pludselig var det ikke længere muligt at kritisere kapitalismen. Der fandtes ikke nogen position, hvorfra det kunne lade sig gøre. De, der hævdede, at der eksisterede et alternativ til de herskende produktionsforhold, var blåøjede idealister, som ikke forstod den nuværende ordens uundgåelighed. La pensée unique benævnte Le Monde diplomatique-redaktøren, Ignacio Ramonet, det.

På godt og ondt fremstår den amerikanske politolog Francis Fukuyamas herostratisk berømmede tese om historiens afslutning som kulminationen på denne udvikling, som nåede svimlende højder med Murens fald. Ifølge Fukuyamas artikel fra 1989, "The End of History and the Last Man", og bogen fra 1992 med samme titel, var vi nået til vejs ende i menneskets ideologiske evolution, det liberale demokrati og markedskapitalismen havde vist sig at være den endelige destination for menneskeheden. Efter et århundrede med de rædsler, vi forbinder med kommunismen 
og fascismen, fra skueprocesser og Gulag til Auschwitz, kan der ikke være andet end enighed om det gunstige i den moderne udgave af det liberale demokrati og den kapitalistiske markedsøkonomi, skriver Fukuyama. Vi har fundet den bedste måde at styre på. Alle de store spørgsmål er blevet løst, derfor er historien forbi.

\section{Lyotards afsked med marxismen}

Lyotard gik slet ikke så langt som Fukuyama, slet ikke. Men han var med til at sætte bolden i bevægelse, da han forviste marxismen til historien og annoncerede det postmoderne samfunds komme. Annoncerede et farvel til de store fortællinger. For det var jo den overordnede tese i Lyotards bog, der blev skrevet som et bestillingsarbejde med titlen "Les problèmes du savoir dans les sociétés industrielles les plus développés” (Vidensproblemet i de mest udviklede industrisamfund) udført for Conseil des universités i Québec: de store fortællinger var på vej ud. For Lyotard var marxismen en af disse fortællinger, og på mange måder den vigtigste af dem.

For Lyotards vedkommende var der nemlig også tale om en selvkritik. Han havde selv en baggrund som militant marxist. Han havde fra starten af I950'erne været tilknyttet gruppen omkring tidsskriftet Socialisme ou Barbarie, der fra 1948 til I965 var det nok vigtigste venstremarxistiske tidsskrift i Frankrig. Med Cornelius Castoriadis og Claude Lefort som frontfigurer udviklede tidsskriftet en radikal marxistisk position mellem Rosa Luxemburg og rådskommunisme. Herfra kunne det både lade sig gøre at analysere den eksplosive udvikling i Frankrig og Vesteuropa efter krigen, hvor der i takt med opbygningen af et konsum- og velfærdssamfund skete en forskydning af de overleverede klassestrukturer hen imod en opdeling af det kapitalistiske samfund i de, der giver ordrer og, de, der udfører ordrer. Dertil tog man det stalinistiske partibureaukrati i Sovjetunionen under kritisk behandling og affejede dets retorik om socialisme som falsk, og endelig adresserede man den igangværende afkoloniseringsproces, som den bl.a. kom til udtryk i Algeriet og andre franske kolonier. Det sidste emne var Lyotards anliggende. Han arbejdede nemlig som gymnasielærer i Algeriet i I950'erne og fik derfor som opgave at rapportere fra den borgerkrigshærgede franske koloni. I sine artikler om Algeriet beskriver Lyotard udbytningen af de algierske bønder og arbejdere og anvender et marxistisk vokabularium - revolution, udbyttede og udbytter, de algierske masser som et revolutionært subjekt - til at beskrive konflikten. Der er tale om en revolutionær krig, hvis perspektiv er en afslutning af udbytningen af Algeriet. Så langt når algerierne dog ikke, og kampen mod kolonimagten er mere en kamp mod national fremmedgørelse end mod social udbytning, noterer Lyotard.

Efter Lyotard bryder med Socialisme ou Barbarie-gruppen i i964, fortsætter han nogle år med at bruge marxismen som analyseredskab og skriver bl.a. i I 668 en kritik af Althusser, "La place de l'aliénation dans le retournement marxiste", hvor han går i rette med Althussers afvisning af fremmedgørelsesbegrebet. Ifølge Lyotard er fremmedgørelsesbegrebet ikke, som Althusser siger, et præ-marxistisk begreb, som den modne Marx forlader, det er tværtimod en kontinuerlig, central ingrediens i 
den marxistiske kritik af kapitalismen og dens dominansformer; fremmedgørelsen er et symptom, som analysen skal tage udgangspunkt i. På dette tidspunkt kan beskrivelsen af fremmedgørelsen som en art symptom (og den begyndende brug af Freud) endnu integreres i marxismen, men kursen er sat, og i forlængelse af et intenst studie af den moderne kunsts revolutionære funktion, afhandlingen Discours, figure fra 1969, hvor Lyotard konsekvent betoner, at kunstværkerne ikke skal underordnes et politisk ærinde, men netop er revolutionære hinsides engagement og budskab, finder der et egentlig opgør med marxismen sted, der for alvor gennemføres med bogen Économie libidinale fra 1974, hvor Lyotard med stor energi totalt kuldkaster den marxistiske fremmedgørelsesteori. Arbejderne er ikke fremmedgjorte, nej, de elsker kapitalens skånselsløse ødelæggelse af deres kroppe, elsker arbejdet i minerne og på fabrikken, de kaster sig med stort begær ud i kapitalens sønderrivning af tidligere fællesskaber og traditioner, familien og landsbyen, og nyder forstadens monstrøse anonymitet osv. Marxismens radikale teoretiske kritik af kapitalismen blev afløst af en intens affirmation af kapitalismens amokløb: "Hvorfor er I så interesseret i proletariatet, politiske intellektuelle? I medlidenhed med hvad? Jeg forstår så udmærket, at man hader jer, hvis man er proletar [...] fordi I ikke tør sige det eneste vigtige, der er at sige, nemlig at man kan nyde, samtidig med at man sluger kapitalens lort.” (I4I) 'Alt fast og solidt fordamper' blev stående som en art program for at slippe ud af marxismens tragiske historie om kapitalens uoprettelige forbrydelse mod mennesket. Lyotard var pludselig i den grad i afdrift fra den revolutionære kritik, som marxismen stod for.

I sin rapport til det québecske universitetsudvalg lægger Lyotard så endegyldigt marxismen i graven på en mere afdæmpet, sociologiserende facon: Marxismen præsenteres nu som en stor fortælling, som tiden er løbet fra. ${ }^{2}$ Der findes ganske vist nogle, der desperat forsøger at holde liv i idéen om klassekampen. Hvis ikke arbejderklassen længere kan udstyres med en katarsisk rolle, men lader sig smelte mere og mere sammen med det højtudviklede samfunds institutioner, så må det være studenterne eller arbejderklasserne i den tredje verden eller de unge uden arbejde eller... Men nej, skriver Lyotard. Det er ikke andet end marxismen som utopi eller håb. Konklusionen er, at marxismen er forældet; Lyotard er klar i sin dom, marxismen er ikke længere en adækvat fortolkningsmatrice, hvormed samfundet kan beskrives og analyseres. Den udgør ikke længere det vokabularium med hvilket, man kan besvare det politiske spørgsmål par excellence: hvad skal og kan vi

2 I parentes skal det bemærkes, at Lyotard forlader denne mere historicistiske og sociologiske ramme i sine efterfølgende bøger, hvor det postmoderne ikke bruges som en epokal betegnelse, men bliver udtryk for en særlig modalitet, der eksemplarisk viser sig som avantgardens eksperimenter og selvkritiske undersøgelser. Lyotard ser senere selv tilbage på sin venstrekommunistiske fortid i de to små tekster: "Mindeskrift over en marxisme. Til Pierre Souyri" fra 1982 og "Muren, golfen og solen. En fabel" fra 1990. I begge tekster bekræfter Lyotard læsningen af marxismen som en stor fortælling, der ikke levner plads til den irreduktible forskel, til strid [différend]. Som Lyotard skriver i teksten om vennen Souyri, der også havde været medlem af Socialisme ou Barbarie: "Hvad nu hvis historien og tænkningen ikke havde behov for denne syntese, hvis paradokserne måtte forblive paradokser, og tvetydigheden af disse universaliteter, som også er partikulariteter, ikke ville blive hævet?" (82). 
gøre? For marxismen var svaret altid at forvandle de lokale arbejderklasser til et selvstændigt subjekt, proletariatet, der kunne lægge kapitalismen i graven. Men som Lyotard skriver, "det sociale grundlag for opdelingsprincippet, klassekampen, er ved at forsvinde”. (3I) Marxismen står dermed uden sit centrale omdrejningspunkt: modsætningen mellem kapital og arbejde, og den har mistet sit subjekt, proletariatet er væk. Lyotards analyse er klar: Marxismen har mistet legitimitet, den er den sidste i rækken af store fortællinger, men nu er også dén blevet overhalet af en ny samfundsstruktur og en ny videnskultur, hvilket er "en effekt af teknikkens og teknologiernes hurtige udvikling fra og med Anden Verdenskrig”. (73)

Hinsides de store fortællinger og på den anden side af marxismens forudsigelse om realiseringen af det kommunistiske samfund spørger Lyotard så i sin rapport, hvad kan legitimiteten baseres på i dag? Svaret finder han i Wittgensteins sprogspilsteori, hvor mangfoldighed er udgangspunktet, og hvor fortællingerne er uden telos. Formerne er morfogenetiske, innovative og ikke-teleologiske. De forskellige sprogspil hierarkiseres ikke, men følger hver deres egne regler og går ikke restløst op $\mathrm{i}$ hinanden, selvom de indlejres i hinanden. For Lyotard bliver sprogspillenes inkommensurabilitet til en beskrivelse af det postmoderne vilkår. Hinsides marxismen og de andre store fortællinger bliver udgangspunktet således en mangfoldighed, det gælder om at undgå at reducere til konsensus eller sammenhæng. Problemet med marxismen er netop, at den ikke er i stand til at redegøre for "sprogpartiklernes pragmatik" (8). Men det handler netop om at kunne agere på baggrund af denne inkommensurabilitet, om at fintune vores følsomhed over for forskellene. Med andre ord ud med marxismens totalitetsbestræbelse, som er ensrettende og åbner for allehånde former for undertrykkelse over for det, der ikke passer til marxismens universalitet, og ind med heterogenitet, uenigheden, det uforenelige.

Lyotards kritik af marxismen, som i La condition postmoderne, eller måske snarere desperate flugt fra marxismen, som i Économie libidinale, var tidstypisk. I forlængelse af maj '68 og det nye venstres kritik af det kedelige fordistiske samfund havde Lyotard og en række andre marxister som Jean Baudrillard og Félix Guattari drejet '68-oprørets libertære tendens over i en quasi-anarkistisk begærsfilosofi, der skulle overskride alle etablerede diskurser og institutioner. Den skandaløse affirmation af begæret var ikke mindst rettet mod den etablerede venstrefløj og dens institutioner som partierne og fagforeningerne, der ganske ofte havde vist sig slet ikke at kunne håndtere de nye klassekonflikter, der var dukket frem i løbet af I96o'erne. Économie libidinale, Deleuze og Guattaris L'anti-œdipe og Baudrillards L'échange symbolique et la mort tog alle afsæt i Marx' beskrivelse af kapitalismens revolutionære tendenser "stadige omvæltninger i produktionen, uafbrudte rystelser af alle sociale tilstande, den evige usikkerhed og bevægelse” (I8) - som i en svimlende bevægelse afvikler gamle fællesskaber og traditioner og frigør mennesket fra feudale og patriarkalske forhold, men referencen til igangværende politiske kampe fortonede sig, og der var ikke længere nogen genkendelig kritisk subjektivitet ud over de paradoksale hypostaseringer af det skizofrene og det libidinale. Det problemkompleks, som Lyotard og de andre forsøgte at adressere, var selvfølgelig, at den historiske materialismes 
forestilling om proletariatet som social aktør i en historisk proces ikke længere gav sig selv og derfor måtte gentænkes hinsides '68 og kapitalens rekuperation af det revolutionære opbrud. Lyotard, Guattari og de andres postmarxistiske eksperimenter var et forsøg på at komme på højde med udviklingen, men det mislykkedes, og på den måde var de paradoksalt nok med til at begrave marxismen og åbne døren for den efterfølgende periodes intense, men usynlige kontrarevolution; usynlig fordi der manglede et vokabularium, hvormed den kontrarevolutionære offensiv kunne analyseres.

Måske var det, fordi Lyotard kom inde fra den mest sofistikerede del af marxismen, nemlig venstremarxismen, at opgøret blev så dramatisk, som det er i Économie libidinale, hvor Marx i den grad bliver gjort til grin. For andre filosoffer i den samme generation som Deleuze og Derrida var det ikke helt så påtrængende, kritikken fandt også sted, men ikke i helt samme hysteriske register, og derfor kunne de også nemmere vende tilbage til Marx i midten af I99o'erne, da det begyndte at stå klart, at afskeden med Marx havde været for omkostningsfuld, at kapitalens globaliseringsbevægelse skulle analyseres, at den apatisk-konstaterende accept af den (neo)-liberaldemokratiske udviklingsmodel var en fejl. Derrida gjorde et første forsøg i Spectres de Marx fra I993, og Deleuze havde planlagt en bog om Marx, La grandeur de Marx, da han sprang ud af vinduet fra sin lejlighed i 1995.

\section{Fra klassekamp til sprogspil}

Teorihistorisk markerer Lyotards tese om de store fortællingers forfald en tydelig cæsur. Den analytiske interesse forskød sig på dette tidspunkt i midten af 1970'erne, i første omgang stod den på totalitarismekritik, i næste omgang var det Auschwitz. Begge fokusområder viste sig desværre hurtigt ikke at være særligt befordrende for den kritiske analyse af det såkaldt postmoderne samfund, og slet ikke den neoliberale kapitalisme. Totalitarismekritikken kørte den nødvendige marxisme-revision helt af sporet, med det resultat at marxismen blev lig med totalitarisme. I Frankrig kom denne vending forst til udtryk som 'de nye filosoffer', der med stor sans for selviscenesættelse angrede deres maoistiske fortid på tv-skærmen og satte lighedstegn mellem marxisme og Gulag. Senere blev det François Furets revisionistiske fortolkning af den franske og russiske revolution som i selve deres væsen totalitære og antidemokratiske. Herhjemme kender vi det som Bent Jensen og konsorters lidet sofistikerede koldkrigsanalyser, der sætter lighedstegn mellem marxismen som politisk ideologi og statsterror (nøjagtig som samme flok interessant nok sætter lighedstegn mellem islam og terrorisme og mener at kunne beskrive verdensreligionen alene som en politisk ideologi). Analysen af nazismens folkemord tog så over, hvor totalitarismekritikken holdt op, og umuliggjorde en politisk-historisk analyse af nazismen, men hvad værre var, så blev Auschwitz under emblemet Holocaust instrumentaliseret som en blåstempling af staten Israels apartheidstyre og den slet skjulte legitimation for opretholdelsen af et postkolonialt Mellemøsten, hvor regionens masser blev fastholdt $i$ en underkastet position af lokale pjalte-despoter støttet af Vesten. 
Dér var Lyotard selvfølgelig ikke, men afskeden med marxismen gled over i en pragmatisk accept af den neoliberal-demokratiske udviklingsmodel. Det var et voldsomt selvopgør, Lyotard afsluttede med sin rapport om det postmoderne samfund og dets nye vidensformer. Et selvopgør som kulturhistorisk også har at gøre med 1968 og rekuperationen af tidens revolutionære opbrud. Det var lykkedes at genskabe forbindelsen tilbage til de revolutionære bevægelser i mellemkrigsårene og rette en sønderlemmende kritik af efterkrigstidens konsum- og velfærdssamfund, men så skete der ikke mere. Den vestlige arbejderbevægelse havde ingen intentioner om at bruge opbruddet, og i løbet af relativt kort tid forsvandt energien. De voldsomme opgør med marxismen fandt selvfølgelig også sted på baggrund af dette forløb. Det nye venstre havde allerede udpeget en lang række tvivlsomme forhold ved den dominerende historiske materialisme, og stalinismen i de europæiske kommunistpartier var et reelt problem. Det var nødvendigt at foretage en eller anden form for 'postmodernisering' af marxismen. Men Lyotard gik for langt, da han opgav idéen om klassekamp og frigørelse. Det var en fejl. Ved at kaste marxismen overbord renoncerede Lyotard på muligheden for at komme med en bredere og mere omfattende beskrivelse af udviklingen i verden.

Hvis La condition postmoderne var en afdæmpet afstandtagen til den revolutionære tradition og marxismen, så udgjorde Économie libidinale og Deleuze og Guattaris L'anti-œdipe tilsammen et anderledes opkørt og larmende brud med '68. Her blev den militante marxisme udsat for så meget kritik, at der ikke var meget tilbage at bygge videre på. Det handlede ikke om den ene eller den anden fortolkning af Marx. Som Lyotard skrev: "Vi vil ikke længere korrigere Marx, genlæse ham eller læse ham som de små althusserianere vil 'læse Kapitalen': fortolke den i overensstemmelse med 'dens sandhed'. Vi har ingen planer om at være sande, at fortælle sandheden om Marx, vi spørger os selv, hvad der er af libido i Marx.” (II8) Freud og venstrefreudianismen (især Reich, men også Marcuse) blev midler til at komme videre fra Marx, at slippe ud af marxismens totaliserende fortælling om klassekamp. Med Freuds begærsbegreb kunne Lyotard og de andre undslippe marxismens forestilling om at kunne kontrollere historiske begivenheder og menneskelig handling, begæret var uforudsigeligt og kunne ikke kontrolleres. Deleuze og Guattari latterliggjorde den militante marxist som en kontrollerede far. En ynkelig autoritet, der desperat og patetisk forsøger at holde samling på tropperne og insisterer på at opretholde den politiske diskurs' renhed. De venstremilitante var ifølge Deleuze og Guattari ikke andet end revolutionens bureaukrater, nogle sølle og magthungrende slaver af den store fortælling om klassekampen. Den kritiske position var ifølge Deleuze og Guattari og Lyotard behæftet med så mange fejl, at det var nødvendigt helt at opgive den. Den praktiske ideologikritik, som Lyotard stadigvæk, om end på en forskudt facon, opretholdt i Discours, figure med idéen om det figurale rum, blev nu erstattet af ren affirmation: "Vi opfinder ikke noget, længere er den ikke, ja, ja, ja, ja." (3II) Som Deleuze og Guattari karakteristisk formulerede det: "Men hvad er den revolutionære vej? Er der nogen? Er det at trække sig tilbage fra verdensmarkedet, som Samir Amin med en underlig genoplivelse af fascismens 'økonomiske 
løsning’ råder tredjeverdenslande til at gøre? Eller er det at gå i den modsatte retning? I endnu højere grad at følge markedets bevægelser, afkodningen og deterritorialiseringen? For måske er strømmene endnu ikke deterritorialiserede nok, ikke afkodede nok [...]. Ikke trække sig tilbage fra processen, men gå længere, accelerere processen". (285) Deteritorialiseringen og desubjektiveringen rummede en mulighed for et alternativ, der ikke abonnerede på en forestilling om autenticitet. Det var analysen. En helt anden måde at tænke subjektivitet på. Men en gentænkning af det revolutionære subjekt hvis mimen af kapitalens deterritorialisering endte med helt at opløse den kritiske position.

Der var et tydeligt element af katarsis over fremhævelsen af begæret på bekostning af den militantes askese. Det var nødvendigt at gentænke forestillingen om subjektivitet hinsides de overleverede emancipationsforestillinger knyttet til marxismens forskellige konkurrerende traditioner fra leninismen over trotskismen til rådskommunismen. Alle hang de fast i suspekte forestillinger om den kommende virkeliggørelse af kommunismen, alle ofrede de nutiden på fremtidens alter, underordnede det snavsede og modsigelsesfyldte hverdagsliv under den politiske kamps rene brudflader. Derfor måtte der skabes andre subjektpositioner eller andre subjektiviteter, der ikke blindt reproducerede loven og begæret efter magten.

\section{Postmodernisme og boblekapitalisme}

Selvom den voldsomme undsigelse af den kritiske position var et forsøg på at gentænke den revolutionære dynamik og dens mulige agenter på baggrund af '68 og rekuperationen af protesterne, så blev effekten mere opløsning end radikalisering. Modstillingen mellem på den ene side den tørre og asketiske revolutionære, den bornerte Marx, "den dydige, lille pige", som Lyotard skriver, og så på den anden side de mobile og intense begærsmaskiner, "den store, skæggede prokurator Marx", der elsker kapitalens opløsende dynamik, åbnede for hedonisme og systemintern individuel nydelse, der passede glimrende med den neoliberale hypostasering af den enkelte. Snarere end en radikalisering af den revolutionære dynamik fandt der en opløsning sted. Revolutionen som fri sex. Og kynisme. Hvorfor investere i en fotokopimaskine, det militante informationsmedie par excellence $i$ begyndelsen af 1970'erne, når man kunne bruge pengene på at lave en bar, som Jacques Rancière kritisk fortæller, Lyotard gjorde på Vincennes-universitetet, hvor de begge underviste (8I).

Lyotard og de andre var gået for langt. For da marxismen forsvandt, forsvandt kapitalismekritikken nemlig også. Der blev selvfølgelig stadigvæk udfoldet forskellige former for kritik, men de havde sjældent, for ikke at sige aldrig, totaliteten som objekt. I forlængelse af det nye venstre og begærsfilosofiens take på '68 fortsatte identitetspolitikkens forskellige retninger med at kritisere køns- og identitetsforhold, men karakteristisk nok komplementerede de identitetspolitiske kritikker sjældent marxismen og forkastede den i stedet som værende en del af det sexistiske patriarkalske system, det handlede om at gøre op med. Det var det samme med 
den postkoloniale kritik; den pegede med rette på marxismens eurocentrisme, men gjorde det også ofte hinsides marxismen og dens forsøg på at adressere totaliteten med henblik på en mulig afvikling af kapitalismen. Og økokritikken fulgte de samme linjer. Det var med andre ord begrænsede kritikker. Vigtige og helt nødvendige kritikker af dominansformer, der var blevet negligeret af marxismen, men kritikker uden et fokus på kapitalismen som et globalt system. Det var problemet. For på den måde kom kapitalismen i perioden fra 1973 til 2008 til at fremstå som det mest adækvate samfundssystem. Hvor der kun var plads til justeringer og mindre rettelser, ikke nogen radikal kritik og grundlæggende omlægning.

Men det er ikke til at komme udenom: Lyotard og de andre tog fejl. Og svært meget endda. For interessant nok tog den neoliberale omstrukturering af samfundet for alvor fart, da Lyotard afviklede marxismen og dens klassekampsperspektiv. På det tidspunkt Lyotard fremkom med sin bestemmelse af det postmoderne samfund, ja netop da pressede den neoliberale løsning sig på som nyt akkumulationsregime og blev dominerende som et forsøg på at håndtere den krise, verdensøkonomien var kommet i ved overgangen fra I960'erne til I970'erne. Lyotard lagde marxismen i graven og tog afsked med klasserne, da den neoliberale kapitalisme skruede op for klassekampen med outsourcing, gæld og nye teknologier. Alle sammen ingredienser der havde til formål at genskabe en tilstrækkelig udbytningsrate for at afbryde profitratens fald.

En af periodens tydeligste udviklingstendenser i verdensøkonomien var, at finanskapitalens rolle blev større og større. I USA svulmede finanskapitalen så meget, at den endte med at bidrage mere til nationalproduktet end den fremstillende virksomhed. Resultatet af denne udvikling var fremkomsten af gigantiske pengebobler, der ikke havde nogen egentlig værdi, men som ikke desto mindre cirkulerede rundt i verdensøkonomien. I 2008 brast boblen så, og den fiktive kapital blev pludselig et problem, som staterne måtte tage sig af ved at gennemføre omfattende sparepolitikker, der har haft frygtelige konsekvenser i en lang række lande, eksempelvis Grækenland.

Som alle andre abonnerede Lyotard på idéen om en såkaldt New Economy, hvor nye teknologier som internettet ville reducere den produktive kapitals betydning for skabelsen af værdi. Lyotard tog jo netop udgangspunkt $i$ "de teknologiske forandringer”, der ifølge ham var ved at finde sted. Det var den teknologiske udvikling, der skabte betingelserne for og nødvendigheden af den sprogspils-baserede, ikketeleologiske legitimation. Som Gayatri Spivak ironisk formulerer det i en kritisk kommentar til Lyotard: "Hil dig, pax electronica!" (370) Selvom Lyotard noterede sig, at der var ved at ske en udvikling væk fra efterkrigstidens statsstyrede moderniseringsparadigme med den keynesianske og fordistiske masseproduktion og konsum, vil - som han formulerede det, "merkantiliseringen af viden ikke kunne lade det privilegium, som de moderne nationalstater havde og stadig har, hvad angår produktionen og udbredelsen af kundskaber, stå uberørt”. (35) Alligevel var han generelt meget ubekymret, for ikke at sige meget affirmativ over for udviklingstendenserne. Som Lyotard selv formulerede det: "[I] de sidste årtier er viden 
blevet den vigtigste produktivkraft". (I5) Groft sagt kan man sige, det var den idé, der led et spektakulært sammenbrud med finanskrisen i 2008, hvor det viste sig, at de enorme summer, der var blevet skabt gennem finanskapital og service, ikke eksisterede. Den såkaldte post-fordistiske økonomi, hvor der blev skabt værdi gennem cirkulation og lån, viste sig at være en illusion. Dels fordi hundrede millioner af mennesker i Latinamerika, Nordafrika, Sydafrika og Asien i samme periode faktisk blev tvunget ud i lønarbejde under slavelignende forhold. Der skete med andre ord en global arbejdsdeling, hvor den 'produktive økonomi' blev lagt uden for Europa og USA og altså ikke forsvandt. Dels fordi det med finanskrisen i 2008 viste sig bare at være papirpenge, der ikke kunne indløses, altså såkaldt fiktiv kapital. Konklusionen ligger lige for: I såvel den nye økonomi som hos Lyotard fandt der en forskydning hen imod viden og sprog sted. En forskydning der dækkede over en manglende forståelse for kapitalens igangværende globalisering og bobleøkonomi. Skiftet fra klasse til sprog legitimerede blot udviklingen og gik hånd i hånd med forestillingen om profit uden lønarbejde.

\section{Selvreform og sammenbrud}

I dag kan vi se den nye økonomi for det, den var. Et ideologisk udtryk for gennemgribende ændringer i den kapitalistiske verdensøkonomi. Det postmoderne opbrud og idéen om sproget som produktivt, noget der af sig selv skaber værdi, passede som hånd $i$ handske med udviklingen.

Mindre dramatisk kan det måske formuleres på følgende måde: Idet Lyotard og konsorter afviklede marxismen, udviklede de en overdreven tiltro til kapitalens evne til selvreform. Den efterfølgende udvikling taler imidlertid desværre sit tydelige sprog. Da Lehmann Brothers indgav konkursbegæring den I5. september 2008 med en gæld på 3.Ioo milliarder danske kroner, var uligheden i verden vokset eksponentielt siden 1979. Og det både globalt og lokalt. Standardlønningernes forskelle var eksploderet, inklusive i Vesteuropa og USA, hvor chefstillinger blev belønnet med lønninger mere end I9o gange større end den gennemsnitlige arbejders løn. I alle de såkaldte ledende økonomier var forskellen mellem rige og fattige vokset markant mellem I980 og 2008, i de nordiske lande og Tyskland med en lille forsinkelse og først for alvor efter 1990. Men overalt var billedet det samme. Uligheden var øget. Globalt var det selvfølgelig blot langt værre. Her var forskellene tænderskærende. Lyotards forudsigelser blev i den grad gjort til skamme, globaliseringen tillod økonomien at virkeliggøre sin mest sumpede grådighed. I retrospektiv fremstår idéen om det postmoderne samfund næsten som det teoretiske udtryk for den neoliberale kapitalisme.

Det er således ikke, fordi klassekampen ikke fandt sted, den var bare usynlig. Den fremstod som en effekt af uomgængelige historiske tendenser, en art naturlove, hvad enten de gik under navne som globalisering eller senere konkurrenceevne. Derfor er historien om den vestlige arbejderbevægelse fra sidst i I970'erne og frem til i dag en historie om nederlag efter nederlag. Kursen blev lagt, da Thatcher og 
Reagan gik til angreb på henholdsvis de britiske minearbejdere og de amerikanske flyledere. Så meget for historiens ironi. Lyotards timing var med andre ord ret dårlig, beskrivelsen af "det økonomiske genopsving" fremstår som helt skæv med tanke på verdensøkonomiens udvikling fra sidst i I960’erne og frem. Efterkrigstidens voldsomme økonomiske vækst, muliggjort af det keynesianske løn-produktivitetsparadigme, hvor arbejderne producerede mere, fik mere i løn og satte gang i forbruget, endte brat og blev afløst af recession. Fra begyndelsen af I970'erne og frem har verdensøkonomien på intet tidspunkt kunnet præstere de samme vækstrater som i den foregående periode, så et økonomisk genopsving var der ikke tale om.

Lyotard nåede at forfatte sin rapport mellem to kriser, men det er karakteristisk, at de seneste 40 år har været en næsten uafbrudt række af kriser: 1973-I975, I980-I982, I990-I99I, 200I-2002 og 2007-?. Set fra et socialt reproduktionsperspektiv, fremstår perioden næsten som en ny trediveårskrig ikke ulig den, der fandt sted fra I9I4 til I945. Som dengang har kapitalen været nødsaget til at devaluere de eksisterende varer i form af arbejdskraft, maskiner og konsumobjekter, indtil der er muliggjort en tilstrækkelig profitrate til en ny ekspansion. Derfor har den stået på faldende produktion, massearbejdsløshed og destruktion af gammel kapital i Vesten, intenst lønslaveri i Asien, Nord- og Sydafrika og Mellemøsten, og ikke et økonomisk genopsving.

I dag står vi så i den største politisk-økonomiske krise siden I930’erne og har hårdt brug for redskaber for at kunne analysere den historiske situation. Som Bernard Stiegler anklagende skriver i États de choc, er den postmoderne vending skyld i, at vi står forsvarsløse over for katastrofekapitalismen. (13) Min afsluttende, meget forventelige replik vil derfor selvfølgelig være, at situationen kræver en tilbagevenden til marxismen. Marxismen tilbyder nemlig et helhedsperspektiv på verden, der forener en analyse af samfundets fundament med en analyse af samfundets ideologiske former. Marxismen er en kritisk analyse af kapitalismen, der er en historisk specifik samfundsformation, kendetegnet ved produktionen og cirkulationen af varer. Men som ikke er et naturligt endepunkt for historien. Historien gik ikke i stå. Hvis den gjorde, så er den da i den grad kommet i gang igen efter 2008 og 20II, hvor der fandt protester mod den neoliberale kapitalisme sted i stor stil. Derfor har marxismen stadigvæk en funktion som videnskabelig og politisk intervention, der kortlægger det kapitalistiske system og den kapitalistiske produktionsmåde, deres grundformer som lønarbejdet og pengeformen, deres prægning af de politiske institutioner og de kulturelle udtryk, og peger på deres mulige ophævelse. Vi er med andre ord tilbage i I972, da Lyotard og de andre indledte en selvkritik, der imidlertid endte med en accept af den neoliberal-demokratiske udviklingsmodel, med affirmation af kapitalen i dens mest grådige form. Eller det vil sige, det er vi ikke, altså tilbage i I972. Vi er på den ene side bedre stillet, fordi den europæiske arbejderbevægelse og det sovjetiske socialisme-i-et-land ikke længere udgør et alternativ til systemet. Det gør de ikke (det gjorde de heller ikke dengang, det vidste Lyotard så udmærket, men det var der mange andre, der ikke forstod). Men vi er på den anden side dårligere stillet, fordi 40 års intens neoliberalisme har ødelagt 
det marxistiske vokabularium og bandlyst begreber som klassekamp og revolution. Slaphedens epoke er måske ved at være forbi, måske.

\section{LITTERATURLISTE}

Anderson, Perry. "Renewals". New Left Review: New Series, I, (2000): I-20.

Bolt, Mikkel. "Kontrolsamfund og kanonbådsdiplomati”. idem. En anden verden. Små kritiske epistler om de seneste årtiers antikapitalistiske satsninger $i$ kunst og politik og forsogene på at udradere dem.

København: Nebula, 20II, 24I-260.

Bolt, Mikkel. Krise til opstand. Noter om det igangvarende sammenbrud. Aarhus: Antipyrine, 2013.

Christofferson, Michael Scott. French Intellectuals Against the Left: The Antitotalitarian Moment of the I970s.

New York: Berghahn Books, 2004.

Deleuze, Gilles og Félix Guattari. L’anti-edipe. Paris: Les Éditions de Minuit, 1972.

Fukuyama, Francis. Historiens afslutning og det sidste menneske [The End of History and the Last Man, 1992], oversat af Ole Lindegård Henriksen. København: Informations Forlag, 2009.

Lyotard, Jean-François. La guerre des Algériens. Écrits 1956-I963. Paris: Galilée, 1989.

Lyotard, Jean-François. "La place de l'aliénation dans le retournement marxiste" [1969]. Dérive à partir de Marx et Freud. Paris: Galilée, I994, 35-I05.

Lyotard, Jean-François. Économie libidinale [1974]. Paris: Les Éditions de Minuit, 200I.

Lyotard, Jean-François. Viden og det postmoderne samfund [La condition postmoderne, 1979], oversat af Finn Frandsen. Århus: Slagmarks Skyttegravsserie, 1996.

Lyotard, Jean- François. "Svar på spørgsmålet: Hvad er det postmoderne?” [“Réponse à la question: qu'est-ce que le postmoderne?”, 1982], oversat af Finn Frandsen \& Niels Brügger. Det postmoderne forklaret for born [Le postmoderne expliqué aux enfants, 1985]. København: Akademisk Forlag, 1986, 7-23.

Lyotard, Jean-François. "Mindeskrift over en marxisme. Til Pierre Souyri" ["Mémorial pour un marxisme. À Pierre Souyri”, 1982], oversat af Finn Frandsen. Vandringer [Pérégrinations, 1990]. København: Gyldendal, 1998, 77-IIO.

Lyotard, Jean-François. "Muren, golfen og solen. En fabel" ["The Wall, the Gulf, and the Sun: A Fable" (foredrag oprindeligt holdt på engelsk), [1990], oversat af Andreas Brøgger. København: Det kgl. Danske Kunstakademi, 1993.

Marx, Karl og Friedrich Engels. Det kommunistiske partis manifest [Manifest der kommunistischen Partei, I848], oversat af Sven Brüel. København: Rhodos, I970.

Rancière, Jacques. La méthode de l'égalité. Entretien avec Laurent Jeanpierre et Dork Zabunyan. Paris: Bayard, 2012.

Spivak, Gayatri Chakravorty. A Critique of Postcolonial Reason: Towards a History of the Vanishing Present. Cambridge, MA \& London: Harvard University Press, 1999.

Starr, Peter. Logics of Failed Revolt: French Theory after May '68. Stanford: Stanford University Press, 1995 .

Stiegler, Bernard. États de choc. Bêtise et savoir an XXIe siècle. Paris: Mille et une nuits, 2012. 
